\title{
Prostaglandin F-2 $\alpha$ is transferred from the uterus to the ovary in the sheep by lymphatic and blood vascular pathways
}

\author{
R. B. Heap, I. R. Fleet and M. Hamon \\ AFRC Institute of Animal Physiology, Babraham, Cambridge CB2 4AT, U.K.
}

\begin{abstract}
Summary. $\left[{ }^{3} \mathrm{H}\right]$ Prostaglandin F-2 $\alpha$ (PGF-2 $\left.\alpha\right)$ was infused into a uterine lymphatic vessel or a uterine vein for up to $1 \mathrm{~h}$, or injected into the uterine lumen of anaesthetized non-pregnant sheep 7-15 days after oestrus. After an intraluminal injection, labelled PGF- $2 \alpha$ was recovered in uterine lymph and peak radioactivity was reached $50 \mathrm{~min}$ after injection. $\left[{ }^{3} \mathrm{H}\right] \mathrm{PGF}-2 \alpha$ infused at a constant rate into a uterine lymphatic vessel resulted in a maximum concentration of radioactivity in plasma which was $5 \cdot 6-$ and $1 \cdot 7-$ fold higher in the adjacent utero-ovarian and ovarian vein, respectively, than in carotid arterial plasma. Estimation of the amount of infusate transferred from a lymphatic into ovarian venous blood gave a value $(0.4 \%)$ similar to that for transfer from a uterine vein $(0.3 \%)$. Evidence for local transfer was substantiated by the presence of significantly higher concentrations of ${ }^{3} \mathrm{H}$-labelled compounds in the ovary and corpus luteum adjacent to the site of intra-lymphatic infusion compared with those in the opposite organs. The concentrations in the adjacent ovary and corpus luteum were significantly greater when an intra-lymphatic rather than intra-uterine vein infusion was adopted.

The results show that $\left[{ }^{3} \mathrm{H}\right] \mathrm{PGF}-2 \alpha$ is transferred locally from uterine lymphatic vessels into the adjacent ovary, corpus luteum and ovarian vein.
\end{abstract}

\section{Introduction}

The importance of the close anatomical relationship between the vasculature of the uterus and that of the ovary in the control of luteal function is well established in some, but not all mammalian species (Bendz, 1982). In the sheep this arrangement facilitates the local transfer of regulatory compounds and in 1974 Goding summarized the evidence for the uterine production of prostaglandin (PG) F-2 $\alpha$ and its role as a natural luteolytic agent in the sheep. Subsequent work has largely confirmed these findings and shown that ovarian oestradiol-17 $\beta$ and progesterone regulate the concentration of oxytocin receptors in the endometrium and the subsequent release of PGF- $2 \alpha$ from the uterus (McCracken, Schramm, Barcikowski \& Wilson, 1981). In addition, cloprostenol, a synthetic analogue of PGF-2 $\alpha$, has been found to stimulate the secretion of ovarian oxytocin and its associated neurophysin (Flint \& Sheldrick, 1982, 1983; Watkins, Moore, Flint \& Sheldrick, 1984). These findings emphasize the important interplay between products of the uterus and ovary in the functional regulation of the corpus luteum.

The route by which PGF-2 $\alpha$ is transferred from the uterus to the ovary has been a matter of controversy (see Goding, 1974), but the idea that a countercurrent transfer mechanism exists has gained credence (McCracken et al., 1972; Land, Baird \& Scaramuzzi, 1976). Previous studies have largely concentrated on vascular countercurrent transfer of PGF- $2 \alpha$ from uterine venous blood into ovarian arterial blood by virtue of the apposition of these vessels for a considerable part of their length. During a recent re-examination of the complex utero-ovarian lymphatic network, described earlier by Morris \& Sass (1966), we were impressed by the intimate apposition of uterine lymphatic 
vessels and the ovarian artery and utero-ovarian vein (Staples, Fleet \& Heap, 1982), and we decided to test the hypothesis that PGF- $2 \alpha$ is transferred from afferent uterine lymphatic vessels into the adjacent ovary. We have developed a technique to cannulate a uterine lymphatic vessel near the point of its emergence from the uterine horn for the purpose of infusing isotopically-labelled PGF$2 \alpha$. Blood samples were taken from the ovarian vein close to the ovarian hilus which minimized any disturbance of ovarian haemodynamics but in addition allowed the measurement of the transfer of PGF- $2 \alpha$ into ovarian blood and the determination of ovarian (and luteal) uptake of $\left[{ }^{3} \mathrm{H}\right] \mathrm{PGF}-2 \alpha$ at the end of the experiment.

\section{Materials and Methods}

Animals. Multiparous ewes were obtained from the Institute's flocks of Clun Forest and Friesland sheep. Ovulation was induced by the intramuscular injection of PGF-2 $\alpha$ analogue (cloprostenol: I.C.I. Pharmaceuticals, Alderley Edge, Cheshire) using the procedure described by Acritopoulou, Haresign \& Lamming (1978). Oestrus was detected by mating with a vasectomized ram fitted with a marker, and the day of first marking was designated Day 0. Animals were kept with a vasectomized ram in paddocks adjacent to the laboratory, but on the day before an experiment they were housed indoors and food was withheld overnight. Experiments were carried out between Days 7 and 15 of the oestrous cycle.

Experimental. Surgery was performed using sterile procedures. Anaesthesia was induced with pentobarbitone sodium i.v. $(60 \mathrm{mg} / \mathrm{ml}$, Sagatal: May \& Baker, Dagenham) and initially maintained with halothane (Fluothane: I.C.I. Pharmaceuticals) and oxygen inhalation in a re-breathing closed circuit apparatus with $\mathrm{CO}_{2}$ removal by soda lime. After completion of vessel catheterization, anaesthesia was maintained with pentobarbitone sodium $(30 \mathrm{mg} / \mathrm{ml})$ injected i.v. through a catheter introduced into a jugular vein to restore arterial blood pressure to a mean value of $100-120$ $\mathrm{mmHg}$. Systemic blood pressure was monitored throughout by a pressure transducer connected to a carotid artery catheter. The reproductive tract was located by mid-ventral laparotomy and exposed with the aid of a Devine retractor. Lymphatic ducts draining the uterus were localized by the injection of Evans Blue $(1.0 \%$ in sterile saline, $9 \mathrm{~g} \mathrm{NaCl} / 1)$ beneath the serosal layer of the uterine wall at five or more sites along the length of the horn.

For studies of transfer from a uterine lymphatic vessel into the ovarian vasculature the following vessels were catheterized in sequence (Text-fig. 1). An ovarian vein draining the ovary containing a corpus luteum was exposed $2-3 \mathrm{~cm}$ from the ovarian hilus. A polyvinyl catheter (polyvinylchloride, PVC, $0.5 \mathrm{~mm}$ i.d., $0.8 \mathrm{~mm}$ o.d.; Dural Plastics, Dural, New South Wales, Australia) was placed downstream for a distance of about $8-10 \mathrm{~cm}$ to sample utero-ovarian vein blood. A second PVC catheter $(0.5 \mathrm{~mm}$ i.d., $0.8 \mathrm{~mm}$ o.d.) was placed in the same vein and advanced $1-2 \mathrm{~cm}$ retrogradely to sample ovarian vein blood. An adjacent uterine lymphatic vessel which drained towards the utero-ovarian vascular pedicle was carefully dissected away from surrounding tissues near to the uterine horn and two 6/0 silicone-treated non-capillary braided silk sutures were placed underneath the vessel below the site of cannulation. A polythene catheter (polyethylene, $0.5 \mathrm{~mm}$ i.d., $0.8 \mathrm{~mm}$ o.d., Dural Plastics) was tapered to a fine point and introduced into the lymphatic vessel after puncturing it with a 30-gauge hypodermic needle. The catheter was tied into the vessel, connected to a PVC catheter $(0.58 \mathrm{~mm}$ i.d., $0.96 \mathrm{~mm}$ o.d., about $30 \mathrm{~cm}$ long) by means of a metal connector.

For studies of transfer from a uterine vein into the ovarian vasculature, an ovarian (and in some instances a utero-ovarian vein) were catheterized as described above. Subsequently, a PVC infusion catheter $(0.28 \mathrm{~mm}$ i.d., $0.61 \mathrm{~mm}$ o.d.) was introduced about $2 \mathrm{~cm}$ into a small branch of the uterine vein close to the uterine horn.

In some experiments a PVC catheter $(0.5 \mathrm{~mm}$ i.d., $0.8 \mathrm{~mm}$ o.d.) was placed in the tubal end of an isolated uterine horn prepared as described by Fleet \& Heap (1982). After an intra-luminal 


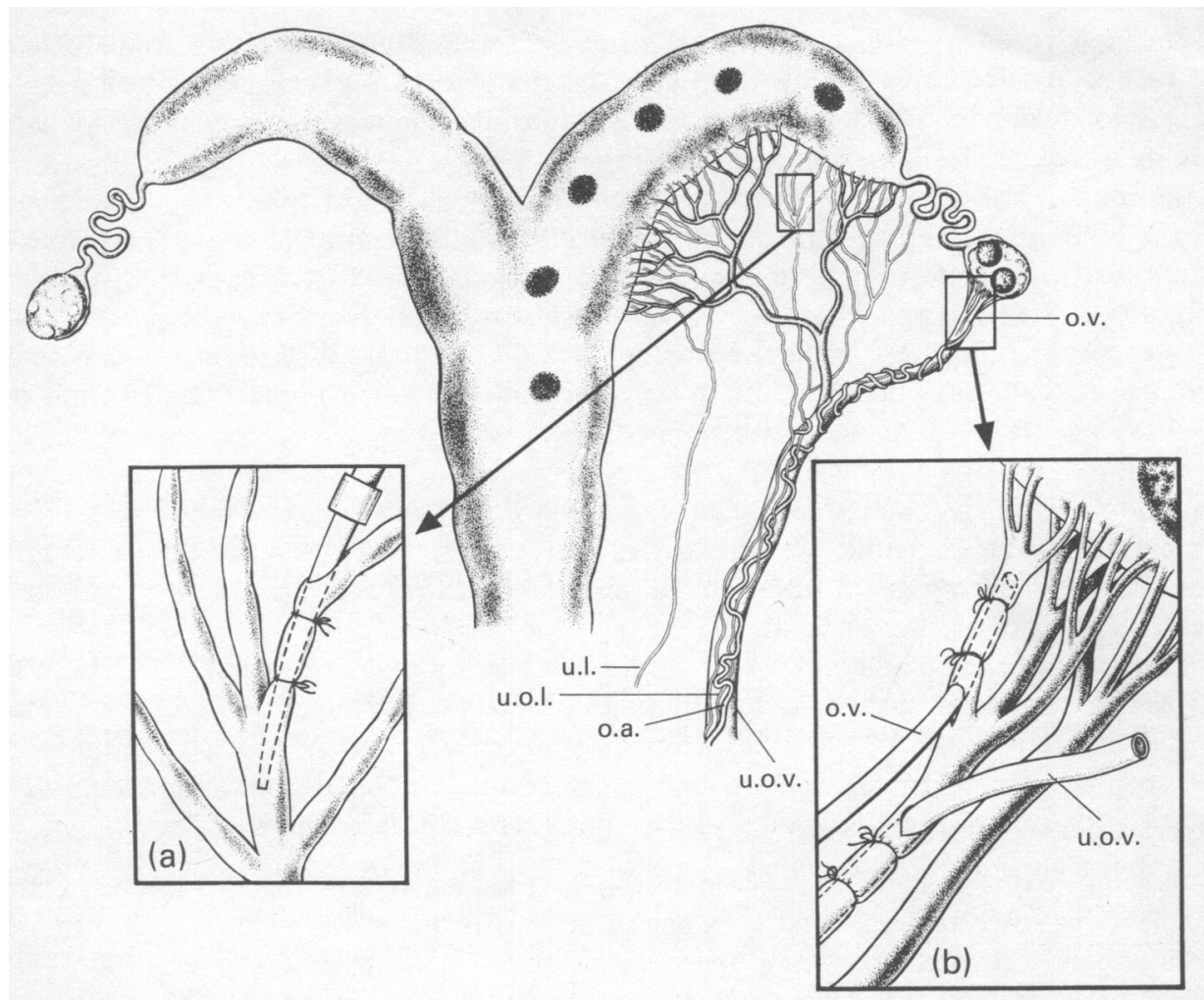

Text-fig. 1. Diagram to show sites of cannulation for study of the transfer of $\left[{ }^{3} \mathrm{H}\right]$ prostaglandin F- $2 \alpha$ from a uterine lymphatic into the adjacent ovarian vasculature. Evans Blue was injected into the myometrial layer at 6 different sites along the length of the uterine horn (shaded). A tapered catheter was inserted into a uterine lymphatic vessel (a), or into a uterine vein in a similar region. Blood samples were taken from a catheter placed into an ovarian vein (o.v.) in a retrograde direction (b), and from a second catheter placed in the same ovarian vein and inserted $8-10 \mathrm{~cm}$ to lie downstream in the utero-ovarian vein (u.o.v.). u.l., uterine lymphatic; u.o.l., utero-ovarian afferent lymphatic; o.a., ovarian artery; u.o.v., utero-ovarian vein.

injection of $\left[{ }^{3} \mathrm{H}\right] \mathrm{PGF}-2 \alpha$, uterine lymph was collected from a single afferent lymphatic vessel previously cannulated alongside the utero-ovarian pedicle cranial to the para-aortic lymph node by the procedure described by Staples et al. (1982). The single duct was selected on the basis of size and accessibility, and by its identification after the injection of $0.5 \%$ Evans Blue in $0.9 \% \mathrm{NaCl}(\mathrm{v} / \mathrm{v})$ into uterine tissue. All adjacent lymphatics in the region of cannulation were ligated.

Catheters were filled with heparinized saline $(100 \mathrm{units} / \mathrm{ml})$ at the time of insertion, and before sampling began heparin (about 150 units $/ \mathrm{kg}$ ) was given i.v. Blood samples were normally taken every $5 \mathrm{~min}$ for the first $90 \mathrm{~min}$ followed by samples at 100,110 and $120 \mathrm{~min}$ after the start of an infusion. Samples were taken simultaneously from an ovarian vein $(2 \mathrm{ml})$, utero-ovarian vein $(2 \mathrm{ml})$ and carotid artery $(5 \mathrm{ml})$. Radiolabelled compounds were infused at a constant rate $(4.1 \mathrm{ml} / \mathrm{h})$ into a uterine lymphatic or uterine vein catheter using an infusion pump (Sage Instruments, Cambridge, MA, U.S.A.). At the end of an intra-lymphatic infusion a dilute solution of Evans Blue was injected into the catheter to establish that no leakage had occurred.

Injections, infusions and sampling. $\left[9-{ }^{3} \mathrm{H}\right]$ Prostaglandin $\mathrm{F}-2 \alpha$ (sp. act. $\left.14 \cdot 8 \mathrm{Ci} / \mathrm{mmol}\right)$ and $13,14-$ dihydro-15-keto-[5,6,8,9,11,12,14(n)- $\left.{ }^{3} \mathrm{H}\right]$ prostaglandin F-2 $\alpha$ (DHK; sp. act. $80 \mathrm{Ci} / \mathrm{mmol}$ ) were obtained from Amersham International PLC (Amersham, U.K.). Aliquots were diluted in $\mathbf{0 . 9} \%$ 
$\mathrm{NaCl}$ and kept frozen at $-10^{\circ} \mathrm{C}$ until required. Infusates were checked by radiochromatography to ensure that radiochemical breakdown had not occurred before the experiment. Small portions of infusate were taken in each experiment to determine the amount of radiolabelled compound infused or injected.

Infusions of $\left[{ }^{3} \mathrm{H}\right] \mathrm{PGF}-2 \alpha$ into a uterine lymphatic $(0 \cdot 66 \pm 0.15 \mu \mathrm{Ci} / \mathrm{min}, 15 \cdot 7 \mathrm{ng} / \mathrm{min})$ or vein $(0.49 \pm 1.13 \mu \mathrm{Ci} / \mathrm{min}, 11.8 \mathrm{ng} / \mathrm{min})$ were continued for up to $60 \mathrm{~min}$. Blood samples were taken simultaneously from an ovarian vein, utero-ovarian vein and carotid artery at every 5 min from 0 to $90 \mathrm{~min}$, and at 100,110 and $120 \mathrm{~min}$ after the start of infusion. Samples were placed in chilled plastic centrifuge tubes kept on ice, centrifuged at $4^{\circ} \mathrm{C}$ and $100 \mu$ portions of plasma taken immediately for counting after the addition of $6 \mathrm{ml}$ scintillation fluid (299, Packard Instrument Co., Downers Grove, IL, U.S.A.) while the remainder was stored at $-20^{\circ} \mathrm{C}$ for further analysis.

When the sampling period was completed, both ovaries and oviducts were removed, trimmed of surrounding tissues and placed in chilled vessels on ice. Corpora lutea and the remaining ovaries were separated, and each oviduct was divided into three approximately equal parts. After mincing with fine scissors, $100 \mathrm{mg}$ quantities of tissue were weighed for counting and the remainder kept frozen at $-20^{\circ} \mathrm{C}$ for further analysis.

For counting of radioactivity in tissues, a known weight of tissue was homogenized at $4^{\circ} \mathrm{C}$ in 1 $\mathrm{ml}$ distilled water and transferred to a scintillation vial with two washes of $100 \mu$ distilled water. An equal volume of solubilizer (NCS, Amersham International) was added to each vial and samples were incubated at $37^{\circ} \mathrm{C}$ for up to $24 \mathrm{~h}$ before the addition of $6 \mathrm{ml}$ scintillation fluid (299) in preparation for counting in a Packard Tricarb 3255 scintillation counter.

Chromatography. For lymph and plasma samples a known volume (up to $3 \mathrm{ml}$ ) was extracted with $6 \mathrm{ml}$ diethyl ether (peroxide free) after acidification with 0.1 volume of citric acid $(50 \mathrm{~g}$ in $70 \mathrm{ml}$ glass distilled water). After extraction the aqueous phase was frozen by standing tubes on solid $\mathrm{CO}_{2}$, and the ether phase was decanted and evaporated to dryness under a stream of nitrogen on a water bath at $37^{\circ} \mathrm{C}$. Methanol $(2 \times 100 \mu \mathrm{l})$ was added to the dry residue, and samples transferred to Kieselgel-60F 254 thin-layer chromatography plates previously run in methanol (A.R.) before use. Plates were developed first in ethyl acetate : methanol : glacial acetic acid ( $100: 10: 1$ by vol.) at $4^{\circ} \mathrm{C}$, dried at room temperature, and re-run in ethyl acetate : acetone : glacial acetic acid $(90: 10: 1$ by vol.) at $4^{\circ} \mathrm{C}$ (Maule Walker \& Poyser, 1978). Authentic ${ }^{3} \mathrm{H}$-labelled standards (PGF- $\alpha \alpha$ and DHK) were run in separate lanes on each plate. After scanning each lane with a Panax thin-layer radiochromatogram scanner (Redhill, Surrey, U.K.), bands of $1 \mathrm{~cm}(0.5 \mathrm{~cm}$ in width in the region of the authentic standards) were scraped off the plates into counting vials. Methanol $(100 \mu \mathrm{l})$ followed by 6 $\mathrm{ml}$ scintillation fluid 299 was added before counting. The chromatographic mobility of different prostaglandins relative to the solvent front ( 1.0$)$ was as follows: PGF-2 $\beta, 0.23$; PGF-2 $\alpha, 0.33 ; 13,14-$ dihydro-PGF-1 $\alpha, 0.49$; PGE-1, 0.51; PGE-2, 0.51; 13,14-dihydro-PGE-1, 0.64; 13,14-dihydro-15keto-PGF-2 $\alpha, 0.60$; PGB-2, 0.77; 13,14-dihydro-15-keto-PGE-2, 0.77 (Maule Walker, 1975; Maule Walker \& Poyser, 1978).

For tissues, a known weight was removed and immediately homogenized in a glass PotterElvehjem homogenizer in $2 \mathrm{ml}$ ice-cold glass-distilled water. Samples were transferred into extraction tubes with 2 washes of distilled water $(8.5 \mathrm{ml})$ and acidified with 0.1 volume citric acid as described above. The samples were extracted with $10 \mathrm{ml}$ diethyl ether and thereafter treated in the same manner as plasma samples.

The recovery of a known amount of $\left[{ }^{3} \mathrm{H}\right] \mathrm{PGF}-2 \alpha$ and $\left[{ }^{3} \mathrm{H}\right] \mathrm{DHK}$ added to plasma from an ovariectomized sheep, and then extracted and chromatographed was $58.2 \pm 0.8$ and $51 \cdot 3 \pm 1.6 \%$, respectively (6 observations). Recoveries of $\left[{ }^{3} \mathrm{H}\right] \mathrm{PGF}-2 \alpha$ and $\left[{ }^{3} \mathrm{H}\right] \mathrm{DHK}$ added to pooled samples of ovarian tissue were $71 \cdot 0 \pm 4.9$ and $50 \cdot 2 \pm 4 \cdot 2 \%$, respectively, and for luteal tissue, $52.6 \pm 4.4$ and $46.6 \pm 2.5 \%$, respectively. All subsequent results were corrected for procedural losses.

Calculations. Veno-arterial differences were calculated from the concentration of ${ }^{3} \mathrm{H}$-labelled compounds in ovarian or utero-ovarian plasma minus that in the carotid artery. Each value was 
plotted against time after start of infusion, the area under the curve measured by trapezoidal integration (Apple II and Graphics Tablet) and expressed as the amount of radioactivity. Transfer was calculated as the product of the amount of radioactivity and published values of plasma flow (Harrison \& Heap, 1978; Fleet \& Heap, 1982) and expressed as a percentage of the total amount of [ $\left.{ }^{3} \mathrm{H}\right]$ PGF- $2 \alpha$ infused. Results were transformed to natural logarithm values to standardize variances and evaluated statistically by covariance analysis which corrected for any difference in infusion rates between various experiments.

\section{Results}

\section{Transfer of $P G F-2 \alpha$ from the uterus into afferent lymph}

Evidence was obtained for the transfer of $\left[{ }^{3} \mathrm{H}\right] \mathrm{PGF}-2 \alpha$ from the uterus into uterine lymph (4 sheep). After injection of labelled PGF- $2 \alpha$ into the lumen of an isolated uterine horn the amount of radioactivity recovered in uterine lymph increased after about $20 \mathrm{~min}$ following the injection and remained high for at least $60 \mathrm{~min}$ whereas that in uterine vein plasma reached peak values within 20 min of the injection and then declined (Text-fig. 2). Thin-layer chromatographic separation of extracts of uterine lymph and utero-ovarian plasma showed two peaks of radioactivity in each sample with the same chromatographic mobilities as PGF-2 $\alpha$ and DHK (Text-fig. 3).

\section{Transfer of PGF-2 $\alpha$ from uterine afferent lymph into the ovarian vasculature}

PGF- $2 \alpha$ was infused into a uterine lymphatic vessel in Sheep H351 15 days after oestrus. Within 10 min after the start of the infusion the amount of radioactivity in the adjacent utero-ovarian vein was 3-fold higher than that in the ovarian vein. By $30 \mathrm{~min}$, radioactivity in the adjacent uteroovarian and ovarian vein plasma was 10 - and 2 -fold higher (respectively) than that in carotid

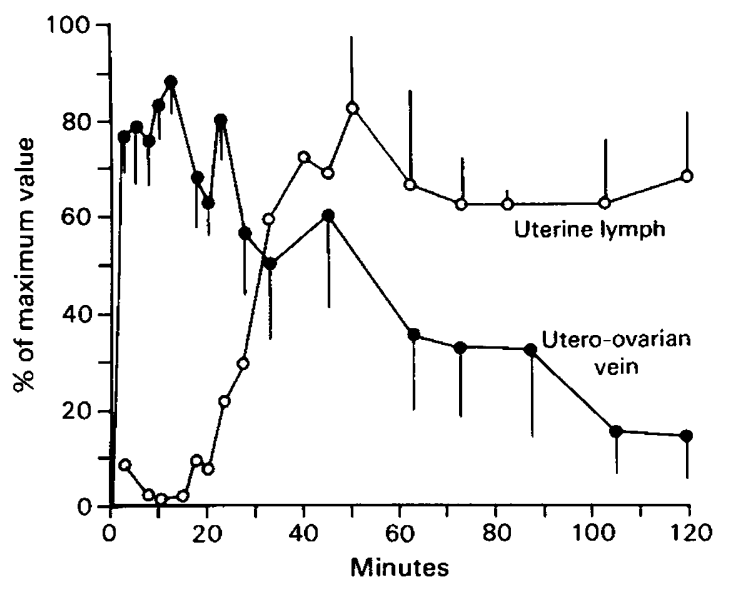

Text-fig. 2. Transfer of $\left[{ }^{3} \mathrm{H}\right]$ prostaglandin F-2 $\alpha$ (PGF-2 $\left.\alpha\right)$ from the uterine lumen of 4 nonpregnant sheep 14-15 days after ovulation. $\left[{ }^{3} \mathrm{H}\right] \mathrm{PGF}-2 \alpha(10 \mu \mathrm{Ci})$ was injected into the lumen of an isolated uterine horn as described in the text ('Materials and Methods') and samples of utero-ovarian venous blood and uterine lymph were collected. The total amount of radioactivity in each sample was measured, and the results expressed as a percentage of the maximum value observed in each experiment. Mean values $( \pm$ s.e.m.) are plotted; the low flow rate of uterine lymph precluded the collection of samples at each time point up to $50 \mathrm{~min}$ after the start of the experiment. 


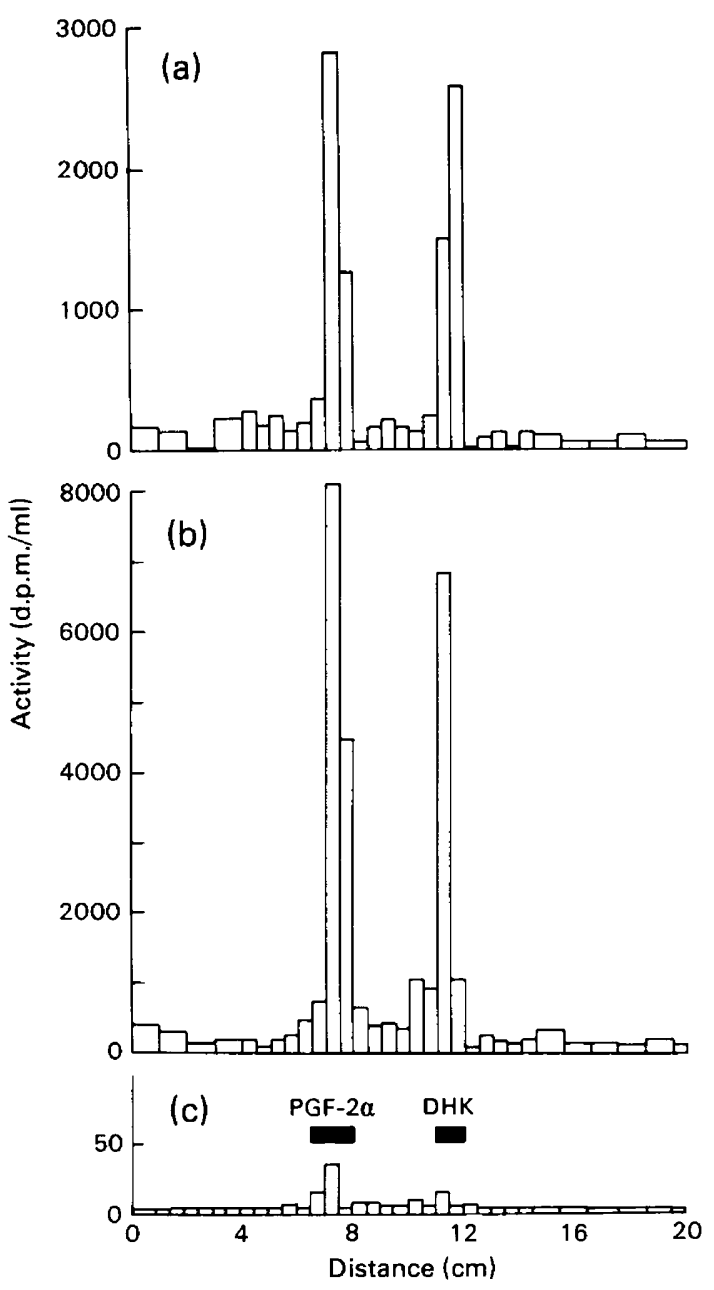

Text-fig. 3. Radiochromatograms of (a) uterine lymph, (b) utero-ovarian plasma and (c) carotid arterial plasma after the injection of $\left[{ }^{3} \mathrm{H}\right] \mathrm{PGF}-2 \alpha(60 \mu \mathrm{Ci})$ into the lumen of an isolated uterine horn in one sheep as described in legend of Text-fig. 2. Four lymph samples collected between 0 and 112 min after the intra-luminal injection were pooled and the extract from $1 \mathrm{ml}$ was applied to a thin-layer chromatography plate. The utero-ovarian vein and carotid arterial samples selected for analysis were taken at $12 \mathrm{~min}$ and 74-112 min (pooled), respectively, after the start of the experiment. The chromatographic mobility of authentic $\left[{ }^{3} \mathrm{H}\right] \mathrm{PGF}-2 \alpha$ and $\left[{ }^{3} \mathrm{H}\right] \mathrm{DHK}$ are shown in relation to the point of application $(0 \mathrm{~cm})$ and the solvent front $(20 \mathrm{~cm})$.

arterial plasma (Text-fig. 4). Integration of the veno-arterial differences with correction for estimated plasma flow gave total transfer into the ovarian vein and utero-ovarian vein of 0.34 and $4.2 \mu \mathrm{Ci}$, respectively. This represents 0.7 and $8.5 \%$ of the total amount of PGF- $2 \alpha$ infused.

Nine similar experiments were carried out at different times during the second half of the oestrous cycle (infusion rate, $0.66 \pm 0.13 \mu \mathrm{Ci} / \mathrm{min}$ ). There was no consistent trend between the stage of the cycle and percentage transfer of radioactivity and results were pooled (Table 1). Covariance analysis showed that the maximum concentration of radioactivity found in the adjacent ovarian and utero-ovarian vein plasma was 1.6. and 5.7-fold higher than that in arterial plasma, respectively $(P<0.01$ to $P<0.001)$. Estimated transfer into the two veins was 0.4 and $15.8 \%$, respectively. (The estimate of transfer into the adjacent utero-ovarian vein includes that of transfer into the adjacent ovarian vein which joins the ${ }^{\circ}$ ipsilateral uterine vein.) at $04 / 26 / 2023$ 01:14:15PM 


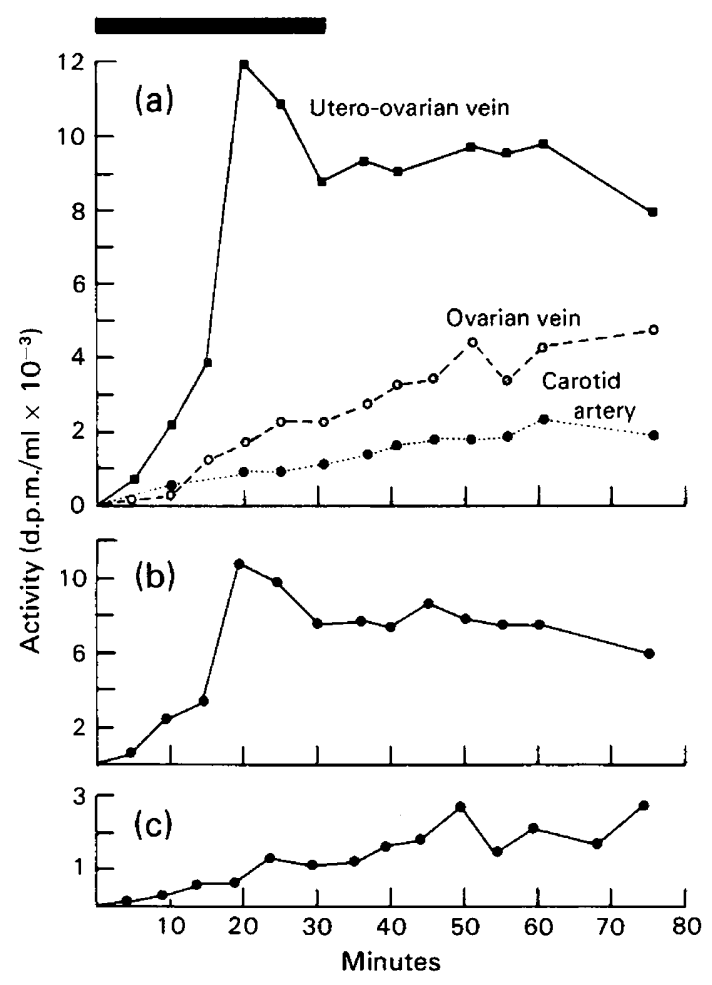

Text-fig. 4. Rate of occurrence of ${ }^{3} \mathrm{H}$-labelled compound in the adjacent utero-ovarian vein and ovarian vein after infusion of $\left[{ }^{3} \mathrm{H}\right] \mathrm{PGF}-2 \alpha(1 \cdot 1 \mu \mathrm{Ci} / \mathrm{min})$ into a uterine afferent lymphatic (black bar) in Sheep H351, 15 days after oestrus. (a) Concentration of radioactivity in the adjacent utero-ovarian and ovarian vein and carotid arterial plasma; (b) veno-arterial difference across the adjacent uterine horn and ovary (utero-ovarian vein - carotid artery); (c) veno-arterial difference across the adjacent ovary (ovarian vein - carotid artery).

Chromatography of plasma extracts showed that $\left[{ }^{3} \mathrm{H}\right] \mathrm{PGF}-2 \alpha$ accounted for $61 \cdot 3 \pm 15 \cdot 2,60 \cdot 6$ \pm 17.6 and $30.8 \pm 11.9 \%$ of the total radioactivity in ovarian venous, uterine venous and carotid arterial plasma, respectively. Comparable values for $\left[{ }^{3} \mathrm{H}\right] \mathrm{DHK}$ were $20 \cdot 4 \pm 7 \cdot 3,12.9 \pm 6 \cdot 2$ and $27 \cdot 2 \pm 7 \cdot 2 \%$, respectively.

\section{Transfer of $P G F-2 \alpha$ from uterine vein into the ovarian vasculature}

To compare the relative transfer of PGF- $2 \alpha$ from a uterine lymphatic with that from the uterine vein, experiments were carried out in which $\left[{ }^{3} \mathrm{H}\right] \mathrm{PGF}-2 \alpha$ was infused into a uterine vein at a rate of $0.49 \pm 0.13 \mu \mathrm{Ci} / \mathrm{min}$. The maximum concentration of radioactivity found in adjacent ovarian venous plasma was not significantly different from that in the carotid arterial plasma (Table 1). The estimated percentage transfer was $0.3 \%$ of the total amount infused, a value similar to that observed with an intra-lymphatic infusion (Table 1).

\section{Transfer of $P G F-2 \alpha$ into the adjacent ovary}

After infusion into a uterine lymphatic vessel or a uterine vein, the concentration of ${ }^{3} \mathrm{H}$-labelled compounds was similar in the adjacent corpus luteum and remaining ovary and significantly higher than that in the opposite ovary (Table 2 ). Chromatography of tissue extracts showed that $\left[{ }^{3} \mathrm{H}\right] \mathrm{PGF}$ $2 \alpha$ represented $21 \cdot 0 \pm 4.8 \%$ and $22 \cdot 8 \pm 6.2 \%$ of the total radioactivity in the adjacent corpus luteum 


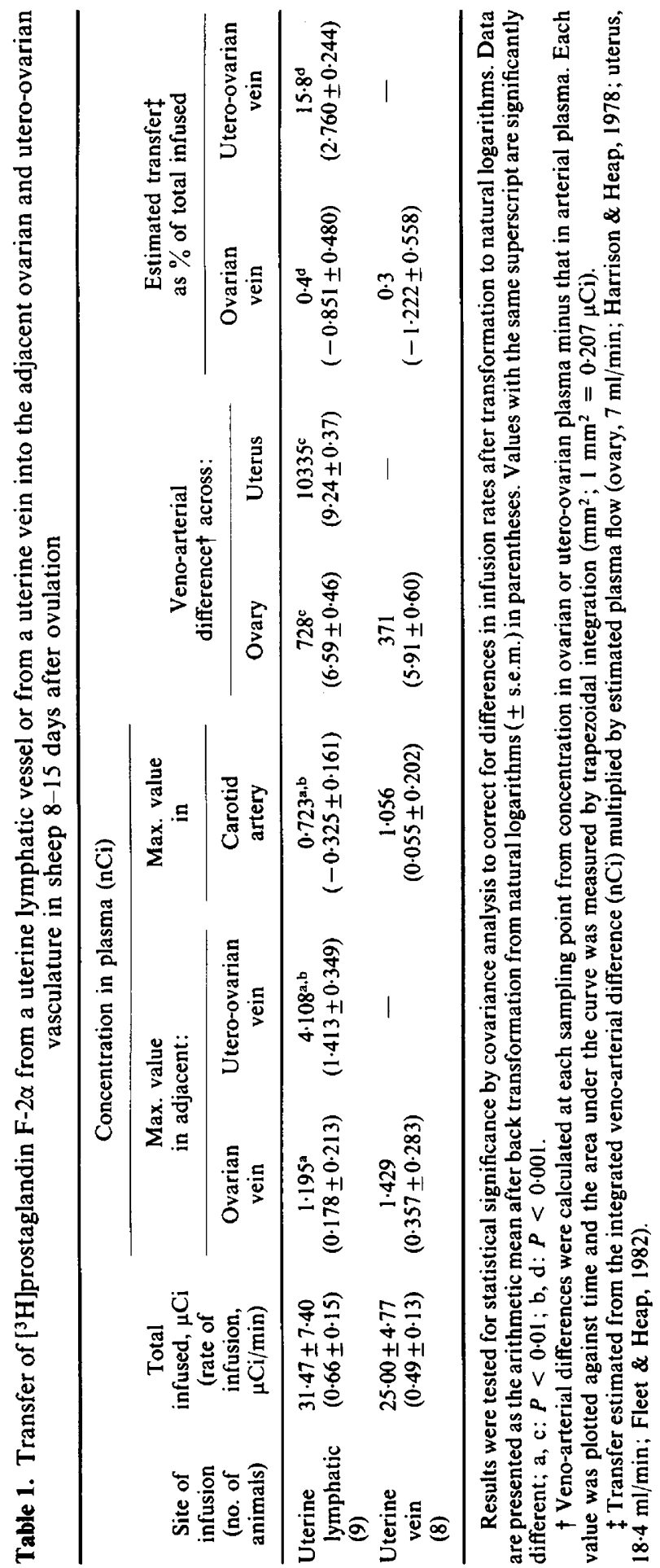




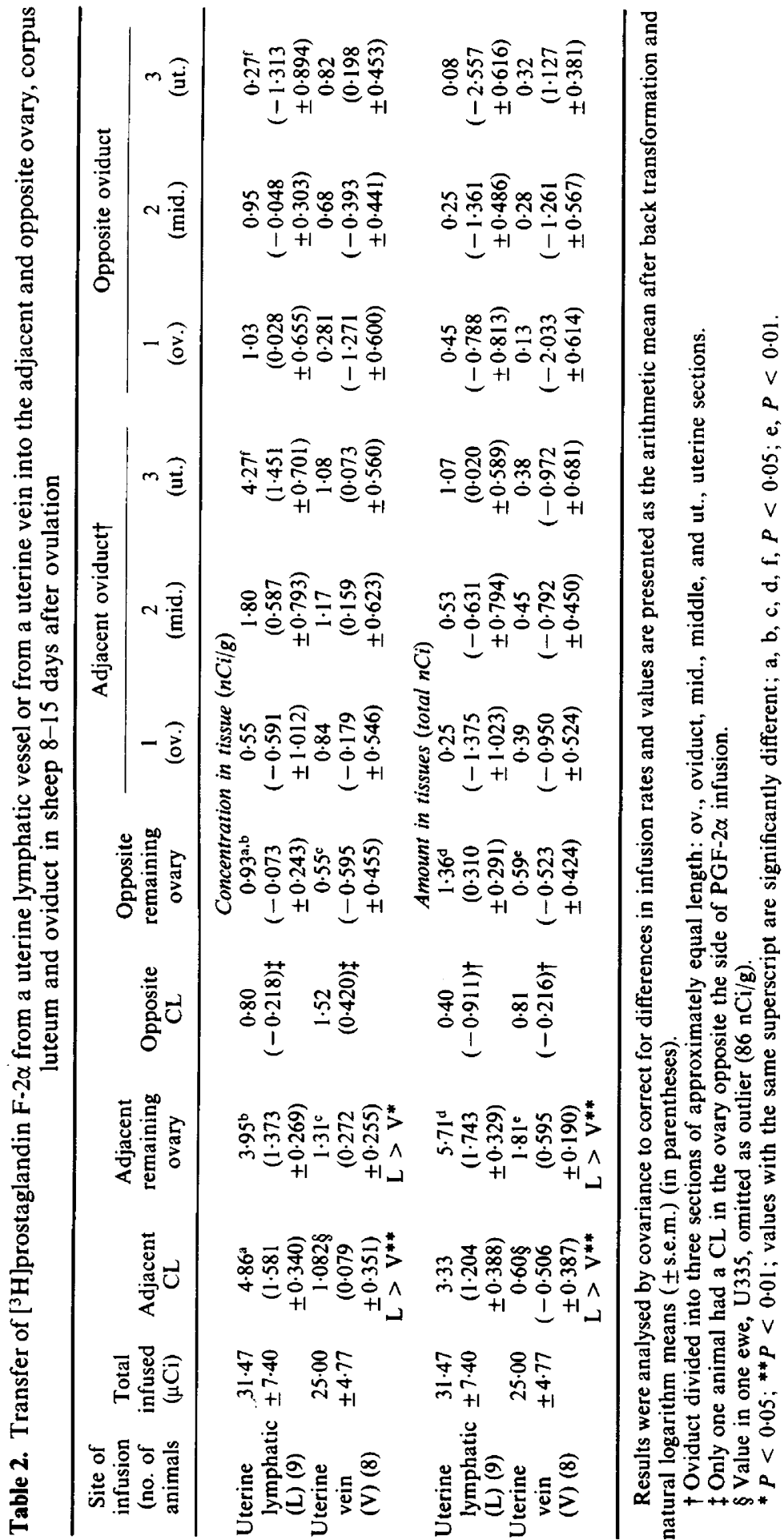


and remaining ovary, respectively. $\left[{ }^{3} \mathrm{H}\right] \mathrm{PGF}-2 \alpha$ represented $8.5 \pm 3.2$ and $9.7 \pm 5.7 \%$ of the total radioactivity in the opposite corpus luteum and opposite ovary, respectively. Comparable values for $\left[{ }^{3} \mathrm{H}\right] \mathrm{DHK}$ were $36 \cdot 8 \pm 20 \cdot 8$ and $21 \cdot 1 \pm 9 \cdot 5 \%$ in the adjacent corpus luteum and remaining ovary, respectively, and $10 \cdot 4 \pm 2 \cdot 1$ and $12 \cdot 3 \pm 2 \cdot 0 \%$ in the opposite corpus luteum and remaining ovary, respectively.

The concentration of ${ }^{3} \mathrm{H}$-labelled compounds in the adjacent ovary and adjacent corpus luteum was significantly higher when $\left[{ }^{3} \mathrm{H}\right] \mathrm{PGF}-2 \alpha$ was infused into a uterine lymphatic rather than a uterine vein (Table 2). No significant difference was apparent in the amount of radioactivity in different regions of the adjacent oviduct. The amount of ${ }^{3} \mathrm{H}$-labelled compounds measured in the uterine portion of the adjacent oviduct, however, was greater than that in the same region of the opposite oviduct (Table 2).

\section{Discussion}

The results show that $\left[{ }^{3} \mathrm{H}\right] \mathrm{PGF}-2 \alpha$ placed in the uterine lumen of sheep is transferred into lymph, along with its metabolite, 13,14-dihydro-15-keto-prostaglandin, presumably formed within the uterine tissue. This means that PGF- $2 \alpha$ enters the extracellular compartment of the uterus drained by lymphatic vessels and is transported into both lymph and venous blood. This observation is consistent with other studies which have shown sequential changes in the concentration of prostaglandin F-2 $\alpha$ in uterine lymph of sheep during the normal oestrous cycle (Abdel Rahim, Bland \& Poyser, 1983; Staples, O'Shea, Harper, Howse \& Thorburn, 1983). The present findings demonstrate that $\left[{ }^{3} \mathrm{H}\right] \mathrm{PGF}-2 \alpha$ is transferred locally from a uterine lymphatic vessel into the adjacent ovarian vasculature. The estimated amount of radiolabelled compounds transferred by this route $(0.4 \%)$ is similar to that obtained when PGF-2 $\alpha$ is infused into a uterine vein (present study, $0.3 \%$; Land et al., 1976, $0 \cdot 1-0.56 \%$ ). The method adopted in this study probably underestimates the amount of radioactivity transferred into the adjacent ovarian vasculature since the concentration observed in ovarian venous blood would be reduced by ovarian uptake and binding by luteal PGF- $2 \alpha$ receptors (Fitz, Mayan, Sawyer \& Niswender, 1982). However, the method permits determination of the amount of ${ }^{3} \mathrm{H}$-labelled compounds in ovarian tissues at the end of the experiment. Thus, at $1 \mathrm{~h}$ after the infusion was stopped the concentration in the adjacent corpus luteum and remaining ovary was significantly higher than in the opposite ovary, and about $20 \%$ was in the form of $\left[{ }^{3} \mathrm{H}\right] \mathrm{PGF}-2 \alpha_{4} \mathrm{~A}$ greater amount of radioactivity was present in the adjacent ovarian tissues after an intra-lymphatic compared with an intra-uterine vein infusion, suggesting that there is a preferential transfer of PGF- $2 \alpha$ from the uterine lymphatics into the adjacent ovary which results from a low lymph flow (Staples et al., 1982) and a large concentration gradient between lymph and ovarian arterial blood.

An important aspect to examine is whether transfer from uterine lymphatics is quantitatively sufficient to have a physiological effect. The total amount of PGF- $2 \alpha$ transferred from multiple lymphatic vessels draining into the adjacent ovarian artery may exceed that from a single uteroovarian vein, and this would make the lymphatic route of transfer of considerable importance (Kotwica, 1980). Yet the reports of previous workers have emphasized the importance of local veno-arterial countercurrent exchange and the adequacy of the main uterine vein and the ovarian artery as the outlet and inlet pathways, respectively, for luteolysin transfer without contributions from other local routes (McCracken, Baird \& Goding, 1971; Barrett et al., 1971; Ginther \& Bisgard, 1972; Ginther, Del Campo \& Rawlings, 1973; Ginther, 1974; Mapletoft \& Ginther, 1975; Ginther, 1981). However, exclusion of the lymphatic route as a means of transfer is difficult to achieve since surgical manipulation of the ovarian and uterine vessels would be accompanied by damage to lymphatic vessels followed by a rapid regeneration of lymphatic vessels and/or redistribution of lymph flow through collateral vessels. The peak endogenous concentration of PGF- $2 \alpha$ in uterine lymph is lower than that in uterine venous blood (Abdel Rahim et al., 1983; 
McCracken et al., 1981) and Whylie, O'Shea \& Staples (1984) and Staples \& Whylie (1984) found that premature luteal regression was induced by a 3-h infusion of PGF- $2 \alpha$ into a uterine lymphatic duct at a dose rate of 20 or $100 \mu \mathrm{g} / \mathrm{h}$ (Day 7 or 8 of cycle). In contrast, McCracken et al. (1981) established that 5 pulses of very low doses given close-arterially into the autotransplanted ovary at Day 12 of a simulated oestrous cycle were effective $(0.04,0.08,0 \cdot 12,0.16$ and $0.20 \mu \mathrm{g} / \mathrm{h})$. Clearly, further studies are required to resolve the relative physiological importance of lymphatic and vascular routes of PGF- $2 \alpha$ transfer. Our findings show that transfer from uterine lymph into the ovarian vasculature is potentially as great as that from uterine venous blood, and that labelled PGF- $2 \alpha$ transferred from the uterus into draining lymph is maintained at a high and steady level much longer than that in uterine venous plasma.

Considering the mechanism of transfer, the close apposition of the uterine lymphatic vessels and the utero-ovarian vein and ovarian artery indicates that countercurrent transfer could be a twostage exchange whereby PGF- $2 \alpha$ from uterine lymph passes first into utero-ovarian venous blood, and then into ovarian arterial blood and the adjacent ovary. Alternatively, it may involve a singlestage exchange from uterine lymph into ovarian arterial blood. The kinetics of transfer observed in Text-fig. 4 appear to support the former hypothesis, since the occurrence of radioactivity in uteroovarian venous blood precedes that in the ovarian vein by about $10 \mathrm{~min}$ and exceeds it in concentration by 2 - to 3-fold. This question may be answered, however, by the simultaneous collection of ovarian arterial blood since uptake by ovarian tissues in the present experiment may have obscured transfer in the initial stages.

Returning to our finding that the concentration of ${ }^{3} \mathrm{H}$-labelled compounds in the adjacent ovary was appreciably higher when $\left[{ }^{3} \mathrm{H}\right] \mathrm{PGF}-2 \alpha$ was infused into a uterine lymphatic vessel rather than a uterine vein, it is notable that a similar difference was not observed in the adjacent oviduct except in respect of the distal third of the oviduct, which was close to the point of infusion. In this context the report of Abdel Rahim et al. (1984) is pertinent since their studies show that the local action of a uterine luteolysin on the adjacent corpus luteum is impaired by the separation of the broad ligament in the region corresponding to that of our intra-lymphatic infusion.

In summary, the results support the hypothesis that $\left[{ }^{3} \mathrm{H}\right] \mathrm{PGF}-2 \alpha$ is transferred from uterine lymphatic vessels into the adjacent ovary and corpus luteum. Estimates of the amount transferred show that they are quantitatively similar whether the PGF- $2 \alpha$ is infused into a uterine lymphatic or a uterine vein. Transfer from the multiple uterine lymphatics present in the mesometrium may mean that this route of transfer has important physiological consequences in the regulation of the corpus luteum.

We thank Dr F. M. Maule Walker, Dr A. P. F. Flint and Dr L. D. Staples for helpful discussions, Mr R. Proudfoot and his staff for the care of experimental animals, Mr S. Clifford for skilled technical assistance, Mr D. E. Walters, AFRC Statistics Group, Cambridge, for help with statistical analysis, Mr J. Fuller for preparing Text-fig. 1, and Mrs J. Tickner for typing the manuscript.

\section{References}

Abdel Rahim, S.E.A., Bland, K.P. \& Poyser, N.L. (1983) Prostaglandin F-2 $\alpha$ and PGE, in uterine lymph during the oestrous cycle in sheep. Prostaglandins, Leukotrienes and Medicine 10, 157-161.

Abdel Rahim, S.E.A., Bland, K.P. \& Poyser, N.L. (1984) Surgical separation of the uterus and ovaries with simultaneous cannulation of the uterine vein extends luteal function in sheep. J. Reprod. Fert. 71, 231-235.

Acritopoulou, S., Haresign, W. \& Lamming, G.E. (1978) Time of ovulation in ewes after treatment with a prostaglandin F-2 $\alpha$ analogue. J. Reprod. Fert. 54, 189-191.
Barrett, S., Blockey, M.A. de B., Brown, J.M., Cumming, I.A., Goding, J.R., Mole, B.J. \& Obst, J.M. (1971) Initiation of the oestrous cycle in the ewe by infusion of PGF $_{2 x}$ to the autotransplanted ovary. $J$. Reprod. Fert. 24, 136-137.

Bendz, A. (1982) Countercurrent exchange in the human female reproductive tract. A study on extrinsic uteroovarian blood vessels. Departments of Obstetrics and Gynecology, Histology and Physiology, University of Göteborg, S-41345 Göteborg, Sweden.

Fitz, T.A., Mayan, M.H., Sawyer, H.R. \& Niswender, G.D. (1982) Characterization of two steroidogenic Downloaded from Bioscientifica.com at 04/26/2023 01:14:15PM 
cell types in the ovine corpus luteum. Biol. Reprod. 27, $703-711$.

Fleet, I.R. \& Heap, R.B. (1982) Uterine blood flow, myometrial activity and their response to adenosine during the peri-implantation period in sheep. $J$. Reprod. Fert. 65, 195-205.

Flint, A.P.F. \& Sheldrick, E.L. (1982) Ovarian secretion of oxytocin is stimulated by prostaglandin. Nature, Lond. 297, 587-588.

Flint, A.P.F. \& Sheldrick, E.L. (1983) Evidence for a systemic role for ovarian oxytocin in luteal regression in sheep. J. Reprod. Fert. 67, 215-225.

Ginther, O.J. (1974) Internal regulation of physiological processes through local venoarterial pathways: a review. J. Anim. Sci. 39, 550-564.

Ginther, O.J. (1981) Luteal blood flow and receptors for LH during $\mathrm{PGF}_{2 \alpha}$-induced luteolysis: production of $\mathrm{PGE}_{2}$ and $\mathrm{PGF}_{2 \alpha}$ during early pregnancy. Acta vet. scand., Suppl. 77, 103-115.

Ginther, O.J. \& Bisgard, G.E. (1972) Role of main uterine vein in local action of an intrauterine device on the corpus luteum in sheep. Am. J. vet. Res. 33, 15831587.

Ginther, O.J., Del Campo, C.H. \& Rawlings, C.A. (1973) Vascular anatomy of the uterus and ovaries and the unilateral luteolytic effect of the uterus: a local venoarterial pathway between uterus and ovary in the sheep. Am. J. vet. Res. 34, 723-728.

Goding, J.R. (1974) The demonstration that PGF-2 $\alpha$ is the uterine luteolysin in the ewe. J. Reprod. Fert. 38, 261-271.

Harrison, F.A. \& Heap, R.B. (1978) Progesterone secretion during pregnancy in sheep with an autotransplanted adrenal and an autotransplanted ovary. J. Reprod. Fert. 54, 153-157.

Kotwica, J. (1980) Mechanism of prostaglandin F-2 $\alpha$ penetration from the horn of the uterus to the ovaries in pigs. J. Reprod. Fert. 59, 237-241.

Land, R.B., Baird, D.T. \& Scaramuzzi, R.J. (1976) Dynamic studies of prostaglandin F-2 $\alpha$ in the uteroovarian circulation of the sheep. J. Reprod. Fert. 47, 209-214.

Mapletoft, R.J. \& Ginther, O.J. (1975) Adequacy of main uterine vein and ovarian artery in the local venoarterial pathway for uterine-induced luteolysis in ewes. Am. J. vet. Res. 36, 957-963.
Maule Walker, F.M. (1975) Prostaglandins and the pregnant animal. Ph.D. thesis, University of Edinburgh.

Maule Walker, F.M. \& Poyser, N.L. (1978) The metabolism of prostaglandins by the guinea-pig uterus with particular reference to corpus luteal maintenance in early pregnancy. Br. J. Pharmac. 62, 177-183.

McCracken, J.A., Baird, D.T. \& Goding, J.R. (1971) Factors affecting the secretion of steroids from the transplanted ovary in the sheep. Recent Prog. Horm. Res. 27, 537-582.

McCracken, J.A., Carlson, J.C., Glew, M.E., Goding, J.R., Baird, D.T., Green, K. \& Samuelsson, B. (1972) Prostaglandin $\mathrm{F}_{2 \alpha}$ identified as a luteolytic hormone in the sheep. Nature, New Biol. 238, 129-134.

McCracken, J.A., Schramm, W., Barcikowski, B. \& Wilson, L., Jr (1981) The identification of prostaglan$\operatorname{din} F_{2 a}$ as a uterine luteolytic hormone and the hormonal control of its synthesis. Acta vet. scand., Suppl. 77, 71-88.

Morris, B. \& Sass, M.B. (1966) The formation of lymph in the ovary. Proc. R. Soc. B 164, 577-591.

Staples, L.D., Fleet, I.R. \& Heap, R.B. (1982) Anatomy of the utero-ovarian lymphatic network and the composition of afferent lymph in relation to the establishment of pregnancy in the sheep and goat. $J$. Reprod. Fert. 64, 409-420.

Staples, L.D. \& Whylie, P.A. (1984) Contribution of the utero-ovarian lymphatic network to the control of corpus luteum function in the ewe. In Reproduction in Sheep, pp. 122-124. Eds D. R. Lindsay \& D. T. Pearce. Australian Academy of Science, Canberra.

Staples, L.D., O'Shea, J.D., Harper, C., Howse, A. \& Thorburn, G.D. (1983) Role of the utero-ovarian lymphatic network in ovine luteolysis. Proc. Aust. Soc. Reprod. Biol., Canberra, 15, 8, Abstr.

Watkins, W.B., Moore, L.G., Flint, A.P.F. \& Sheldrick, E.L. (1984) Secretion of neurophysins by the ovary in sheep. Peptides 5, 61-64.

Whylie, P.A., O'Shea, J.D. \& Staples, L.D. (1984) Infusion of $\mathrm{PGF}_{2 \alpha}$ into uterine lymphatic ducts causes local luteolysis in the ewe. Proc. Aust. Soc. Reprod. Biol., Melbourne 16, 4, Abstr.

Received 8 November 1984 